\title{
THE IMPACT OF SANITATION ON GROUNDWATER NITRATE LEVEL IN BANTUL DISTRICT, BANTUL REGENCY, YOGYAKARTA SPECIAL PROVINCE, INDONESIA
}

\author{
Salpisey Heng ${ }^{* 1}$, Doni Prakasa Eka Putra ${ }^{2}$, and Wahyu Wilopo ${ }^{2}$ \\ ${ }^{1}$ Department of Civil Engineering, Faculty of Engineering, Institute of Technology Cambodia, Cambodia \\ ${ }^{2}$ Department of Geological Engineering, Faculty of Engineering, Universitas Gadjah Mada, Indonesia
}

\begin{abstract}
Bantul is one district of Yogyakarta Special Province which residents mostly use on-site sanitation. Onsite sanitation is well-known for hot-spot system of nitrate groundwater contamination. It is because the wide-practice of failure of on-site sanitation systems. Besides, the failure of on-site sanitation system, it will depend on the age of settlement, population density, sanitation arrangement and sanitation behavior including water use patterns. Because of this, nitrate has leaked to groundwater and polluted many supply wells surrounding the septic systems.

Since the repeated intake of nitrate could cause various acute and chronic effects to human health, especially the infant's health under 3 months (blue baby syndrome), it is crucial to undertake the study of impact of sanitation on groundwater nitrate level in Bantul district to acquire a better understanding of the effect of settlement age, population density, sanitation arrangement and sanitation behavior on the concentration of nitrate in groundwater. In order to recognize or achieve the understanding of this issue, a methodology is conducted by observation directly to the field, including the measuring of groundwater table and the distance of septic tank to well, and also make the questionnaires for the mentioned parameters.

Finally, the result of each factors (Sanitation
\end{abstract}

${ }^{*}$ Corresponding author: SALPISEY HENG, Department of Civil Engineering, Faculty of Engineering, Institute of Technology Cambodia, Cambodia. E-mail: hengsalpisey2000@yahoo.com arrangement, Settlement age, House density) are shown a low relationship with nitrate concentration, although water use patterns does not. However, the combination of these three factors can show up to find out a better correlation than one factor with this nitrate concentration. Although it has a good relationship with nitrate concentration (average), the variation of nitrate concentration from high to low shows a low relationship. Therefore, the importance of groundwater vulnerability cannot be overlooked in explaining the variation in contaminant concentrations because the nitrate concentration in the groundwater does not only depend on contaminant loading but also groundwater vulnerability.

Keywords: Groundwater, on-site sanitation, nitrate concentration, contaminant loading

\section{Introduction}

Sanitation refers to the hygienic disposal or recycling of waste in which an important measure to prevent the outbreak of diseases and thus protect public health and control environmental pollution (IRC International Water and Sanitation Centre, 2007). However, nowadays sanitation refers in most cases only to the hygienic disposal or recycling of human excreta and grey water (waste water from washing, laundry and kitchens) produced by households.

Moreover, the expansion of domestic settlement in urban or rural areas has also brought a 
major concern on groundwater pollution which results from the sanitation systems. It is so far known for a hot-spot system of nitrate groundwater contamination (ARGOSS, 2001). Therefore, it is reasonable that the impact of sanitation on groundwater nitrate level is important to be identified, especially on the aquifer systems covered by unconfined or semi-confined layers and depend on groundwater for much of their water supply.

According to Prastoro (2009), the average concentration of nitrate in shallow groundwater is about $23 \mathrm{mg} / \mathrm{L}$ in Bantul district. Based on WHO (2003), the guideline of nitrate concentration in drinking water should be less than 50 $\mathrm{mg} / \mathrm{L}$. Thus, the value in Bantul is less than the standard. Therefore, it is that the nitrate concentration in shallow groundwater of Bantul still can be used for human consumption. However, the concentration of nitrate up to $10 \mathrm{mg} / \mathrm{L}$ can affect the infant's health (under 3 months) to cause blue baby syndrome. Anyway, the intake of nitrate could result in various acute and chronic health effects. Therefore, it is very important to evaluate the negative impacts of sanitation in order to tackle the problem of nitrate groundwater contamination as well as to minimize the adverse effects to human health, environment and society as a whole. Furthermore, the output from this study could be served as the basis to remediate and restore the quality of groundwater in that area in order to achieve groundwater sustainability.

\section{Study Area}

The study area mainly is conducted in Bantul district with $21.92 \mathrm{~km}^{2}$ (Putra, 2003), located in Bantul regency, Yogyakarta special province, Indonesia, which is a district with 60023 inhabitants (Prastoro, 2009). The area is administered by five different regional authorities including Bantul village, Ringinharjo village, Palbapang village, Trirenggo village and Sabdodadi village. It is bordered by Sewon District on the North, Jetis District on the East, Bambang Lipuro District on the South, Pandak District on the West, and Pajangan District on the North-

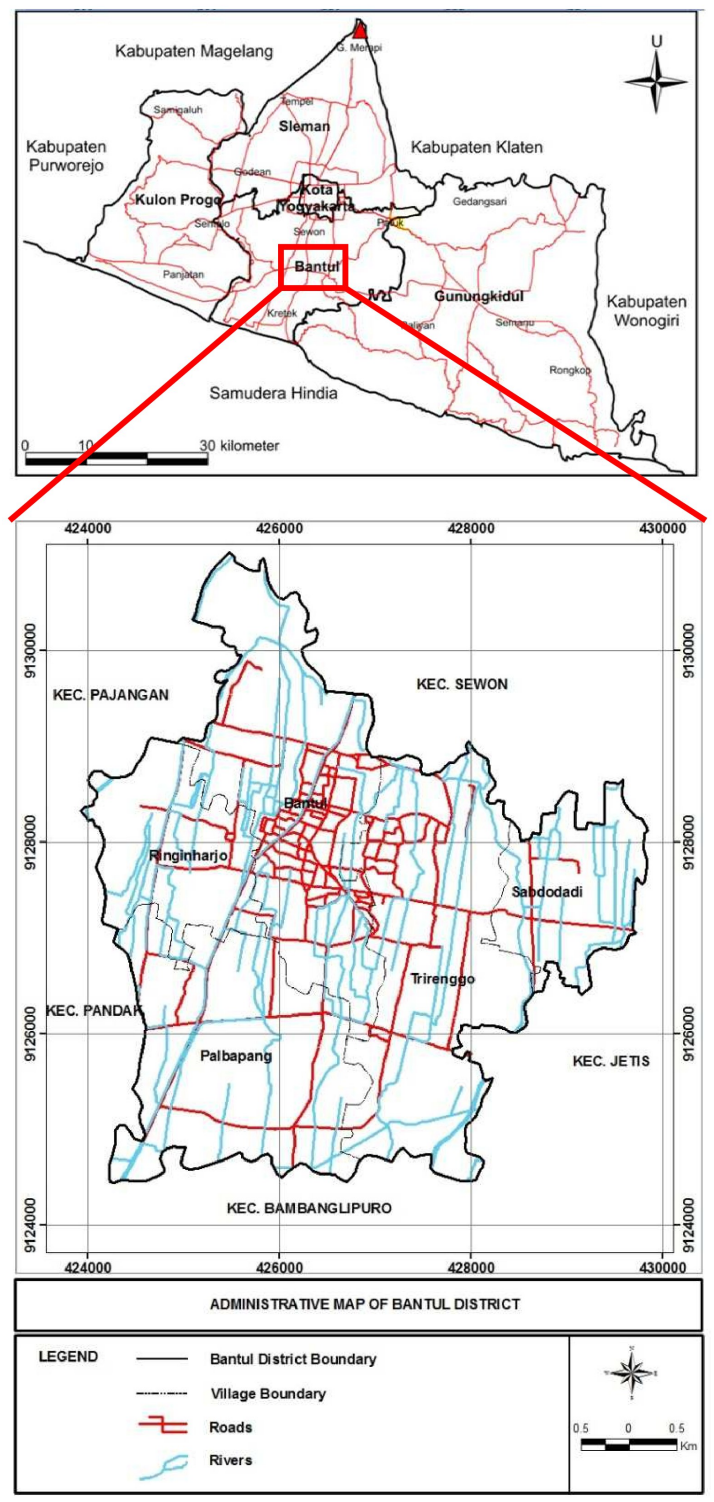

Figure 1: Location of study area.

west as depicted in the administrative map of Bantul district that shows in Figure 1 .

\section{Data Description}

\subsection{Hydrogeological Condition}

\section{Depth to groundwater surface}

After groundwater table measurement from existing dug wells, in the wet season, the depth to groundwater surface of the study area varies from 0.5 to $20 \mathrm{~m}$, with a mean value of about $2 \mathrm{~m}$ (Figure 2). In the dry season, the depth to groundwater surface declines averagely about 


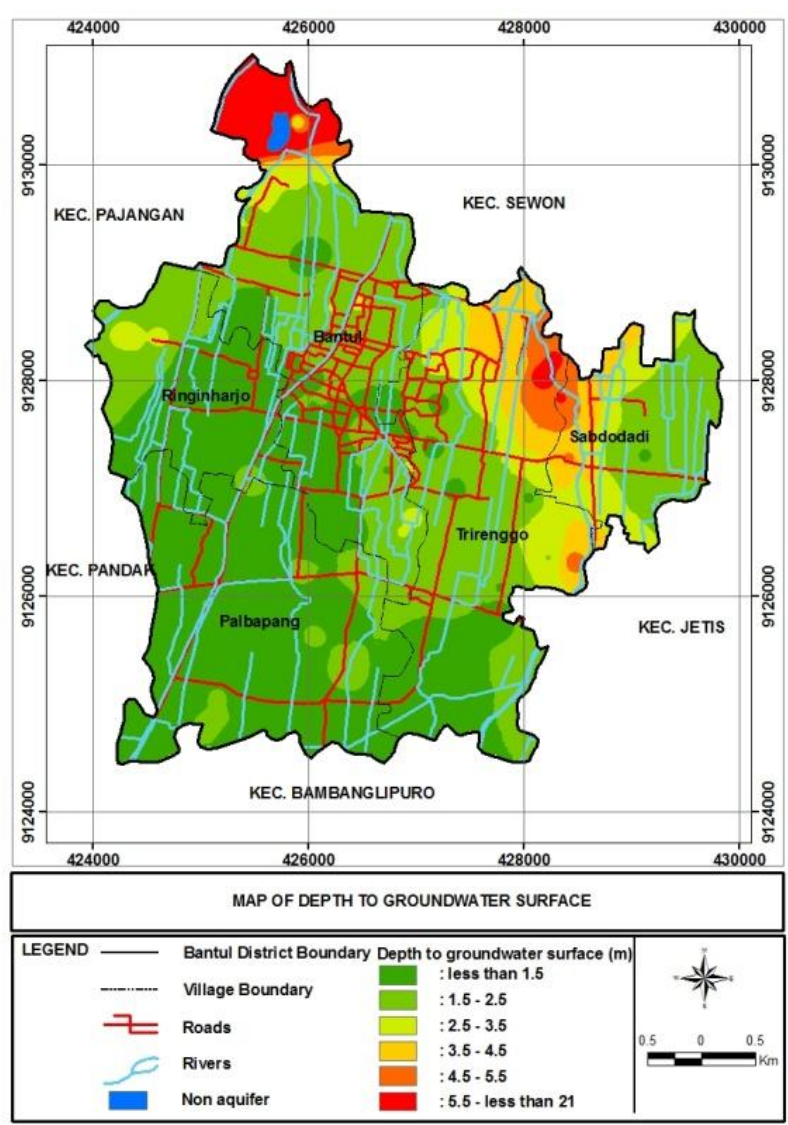

Figure 2: Depth to groundwater surface of the study area.

$3 \mathrm{~m}$ (Prastoro, 2009). These distribution characteristics of groundwater depth are mainly controlled by the local topographical differences. Thus, locally higher area have deeper groundwater surface than the lower area. The map of groundwater depth shown in Figure 2 is actually constructed on the basis of 161 measurements data taken in the wet season and was generated using IDW (Inverse Distance Weighting) interpolation method.

\section{Groundwater flow patterns}

According to Figure 3, the groundwater in the study area moves relatively from the north to the south. Although the general trend of groundwater flowing is from north to south with the hydraulic gradient getting smaller to the south, the groundwater underlying Bantul district is seemingly moving south-west toward Bedog river. Since groundwater flow is heading

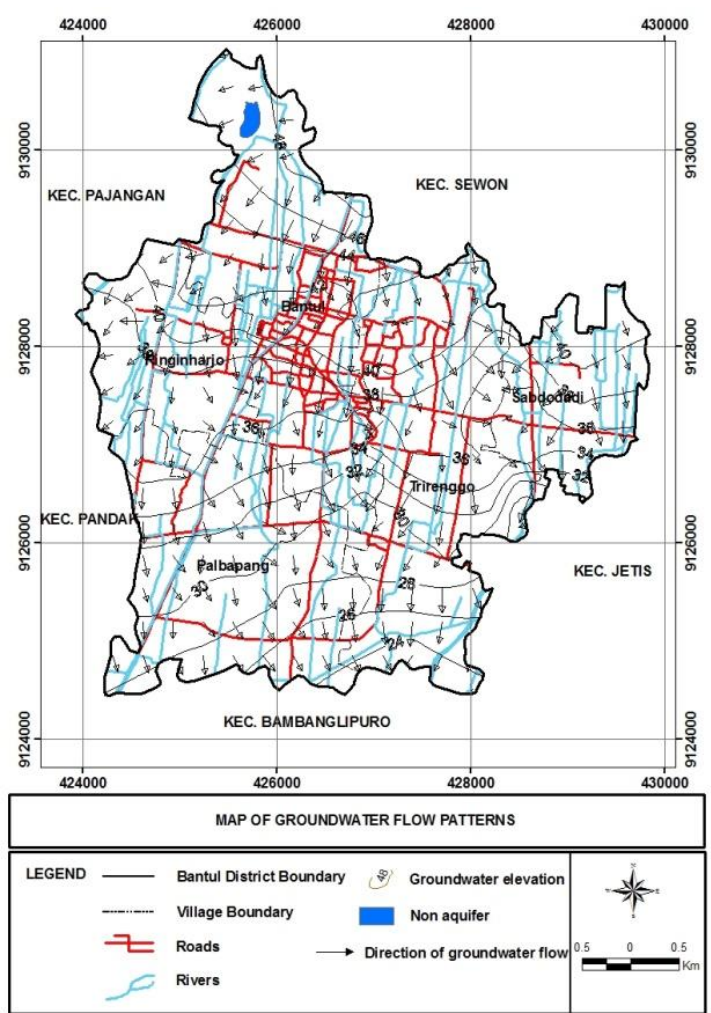

Figure 3: Map of groundwater flow patterns in study area.

to Bedog river, it is obvious that it is a gaining river. Moreover, the flow direction of groundwater can be worked out, it would logically facilitate the researcher by means of characterizing the contaminant plume direction.

\subsection{Contaminant Loading Factors of On-site Sanitation}

\section{Age of settlement}

After surveying, settlement age is classified into three classes including less than 20 years, from 20 to 60 years and more than 60 years. Referring to this classify, the most of houses have less than 20 old and between 20 and 60 old while it has no house more than 60 old in research area. Therefore, it is new and moderate settlement. It is classified into these classes to understand a relationship between them and nitrate concentration. The map of settlement age shown in Figure 4 is actually constructed on the basis of 184 surveyed data was generated us- 


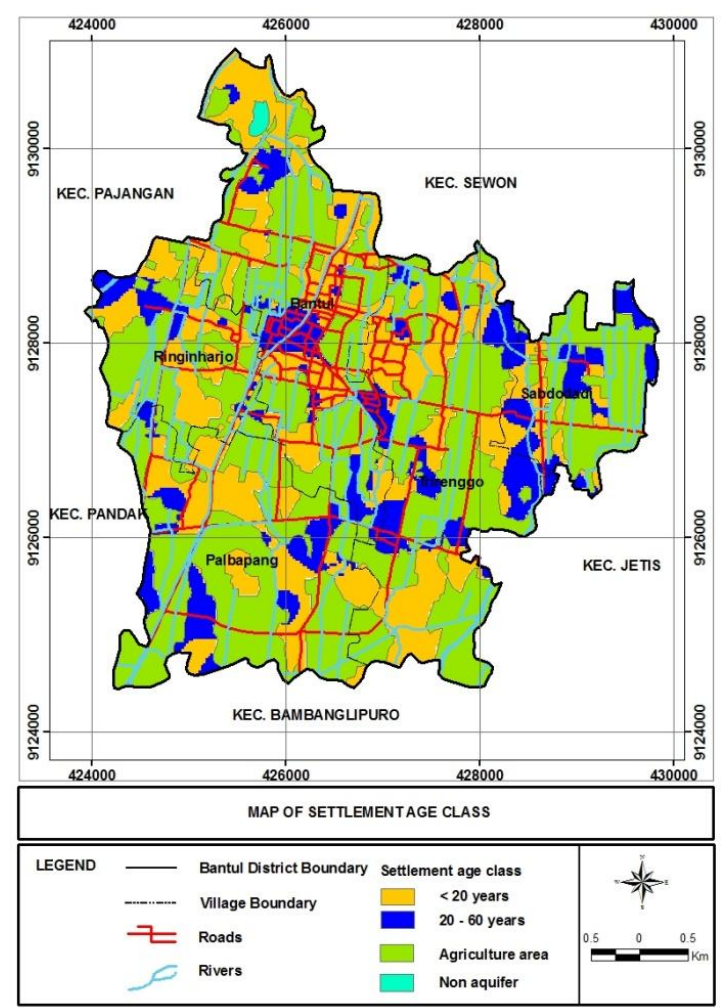

Figure 4: Map of settlement age class.

ing IDW (Inverse Distance Weighting) interpolation method.

\section{House density}

In theory, population density is a main factor affecting the contaminant concentration in groundwater; though, it does not represent the sanitation. Anyway, it is difficult to understand the relationship with nitrate concentration. On the other hand, house density (Figure 5) is representative the sanitation that is important for the studies of the potential contamination of an area triggered by human activities and it is easy to understand the relationship with nitrate concentration. Thus, that is why the house density is chosen as main parameter instead of population density.

\section{Sanitation arrangement}

After sanitation arrangement measurement, it is classified into two classes including less than $10 \mathrm{~m}$ and more than $10 \mathrm{~m}$ to understand a relationship between these classes and nitrate con-

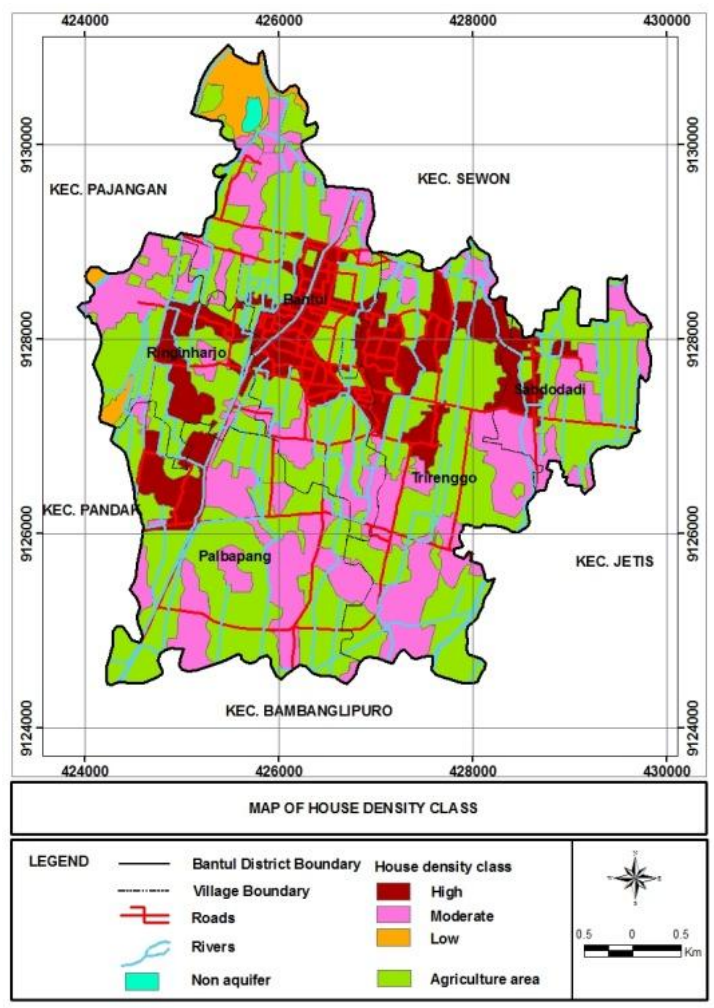

Figure 5: Map of house density class (modified from Prastoro, 2009).

centration. The map of sanitation arrangement shown in Figure 6 is actually constructed on the basis of 184 measurements data was generated using IDW (Inverse Distance Weighting) interpolation method.

\section{Water use patterns}

After water use patterns calculation, it is classified into two classes including less than 1000 $\mathrm{L} /$ day and more than $1000 \mathrm{~L} /$ day to understand a relationship between these classes and nitrate concentration. The detailed information about water use patterns is shown in Figure 7. The map of water use patterns shown in Figure 8 is actually constructed on the basis of 184 surveyed data was generated using IDW (Inverse Distance Weighting) interpolation method. 


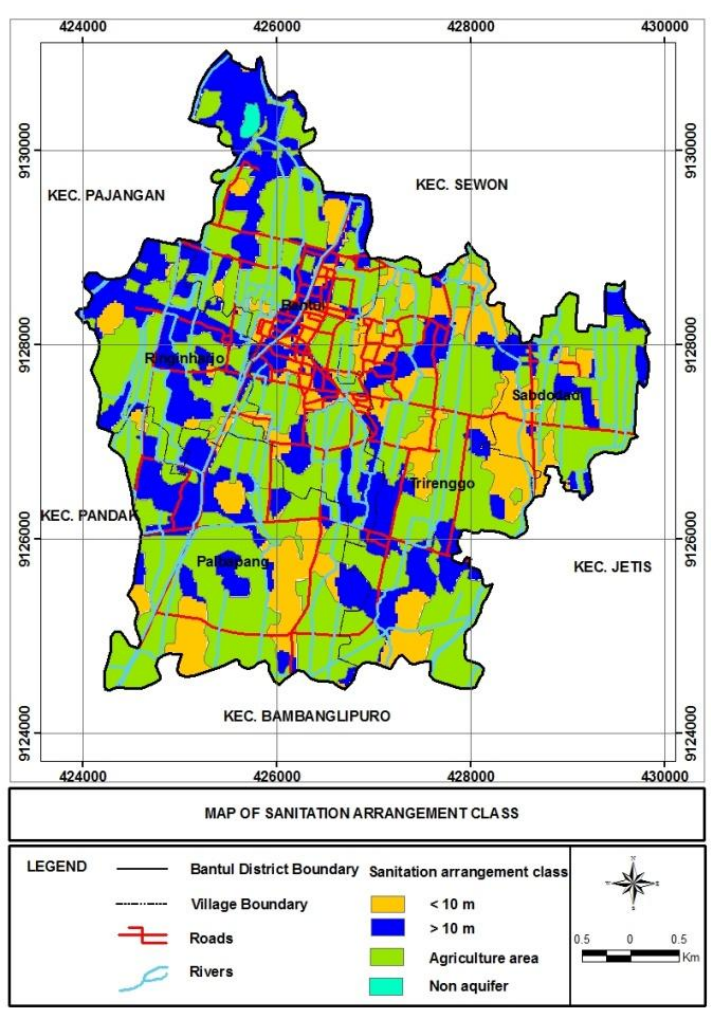

Figure 6: Map of sanitation arrangement class.

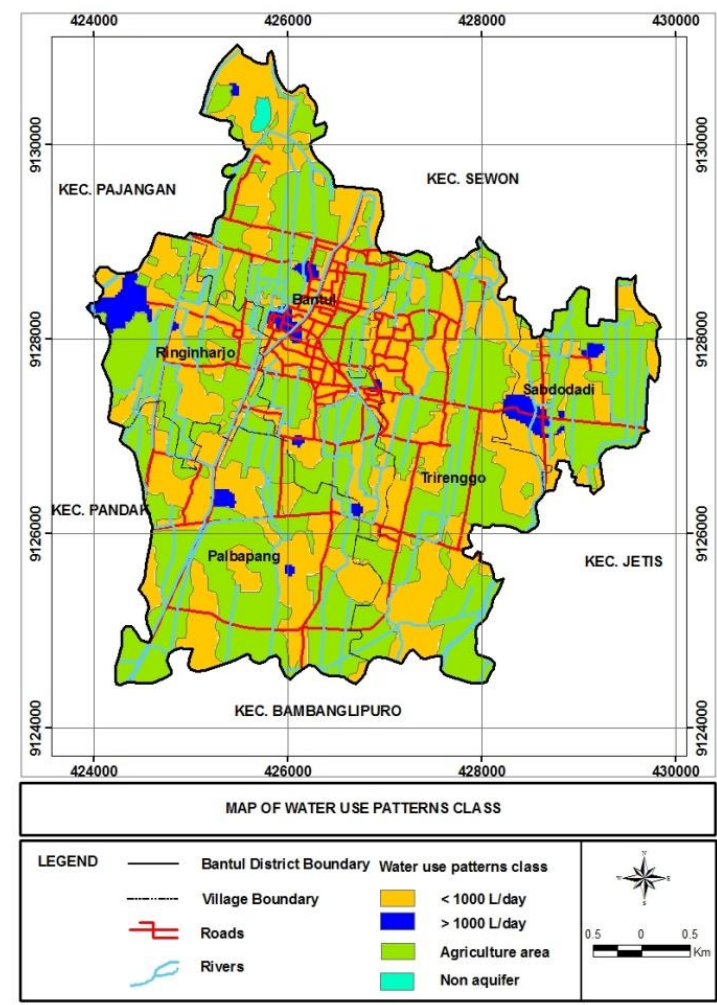

Figure 7: Map of water use patterns class.

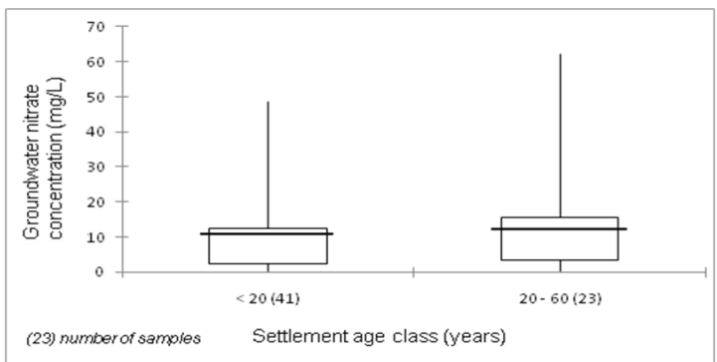

Figure 8: Boxplot diagram of nitrate concentration in shallow groundwater from settlement age class within the study area.

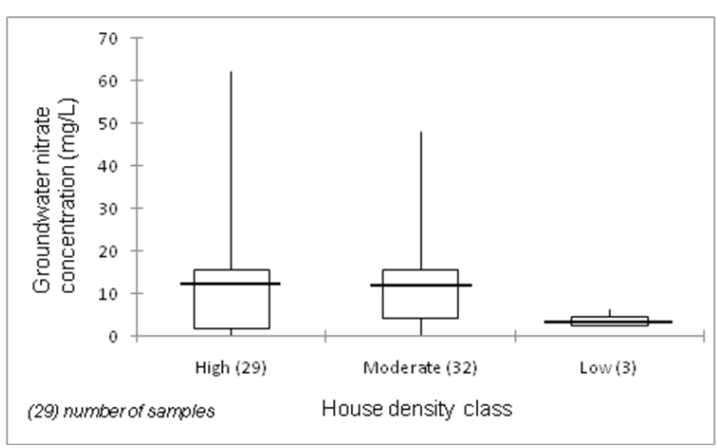

Figure 9: Boxplot diagram of nitrate concentration in shallow groundwater from house density class within the study area.

\section{Evaluation and Discussion}

\subsection{Impact of Individual Factors}

\section{Age of settlement}

According to boxplot diagram (Figure 8), the nitrate concentration is increased by the age of settlement. Thus, this diagram shows a relationship between settlement age and nitrate concentration because the average of nitrate concentration with less than 20 years of settlement age is lower than $20-60$ years of settlement age.

\section{House density}

Based on boxplot diagram (Figure 9), it shows a low relationship between house density and nitrate concentration because high house density and moderate house density is similar with nitrate concentration. 


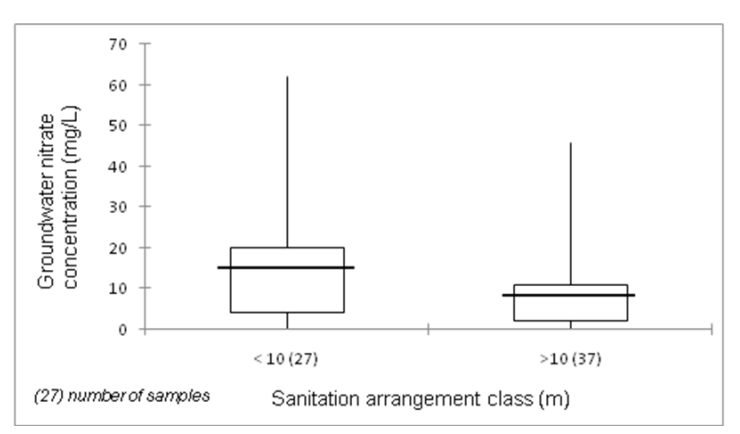

Figure 10: Boxplot diagram of nitrate concentration in shallow groundwater from sanitation arrangement class within the study area.

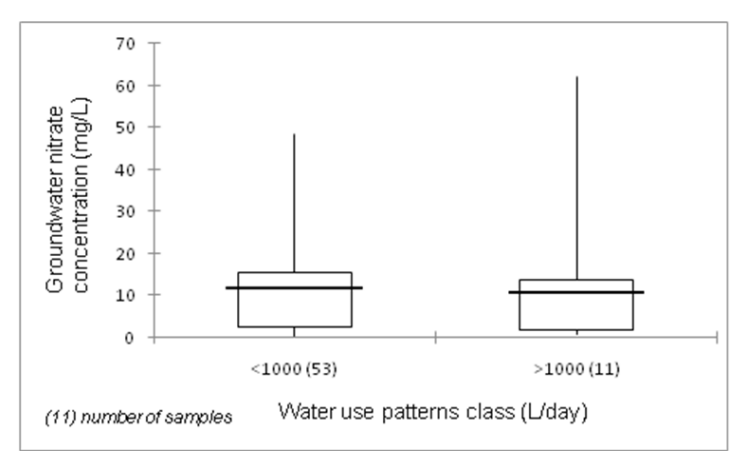

Figure 11: Boxplot diagram of nitrate concentration in shallow groundwater from water use patterns class within the study area.

\section{Sanitation arrangement}

According to boxplot diagram (Figure 10), it shows a relationship between sanitation arrangement and nitrate concentration because the average value of the groundwater nitrate concentration is following this order; sanitation arrangement $(<10 \mathrm{~m})>$ sanitation arrangement (> $10 \mathrm{~m})$.

\section{Water use patterns}

Based on boxplot diagram (Figure 11), it shows a very low relationship between water use patterns class and nitrate concentration because the average value of the nitrate concentration in water use patterns $(<10001 /$ day $)$ is similar with water use patterns (> 1000 l/day).

The summary of correlation value of contaminant loading factors to the nitrate concentration is given in Table 1 .
Table 1: Correlation value of contaminant loading factors to the nitrate concentration.

\begin{tabular}{c|l|c|c}
\hline No. & Parameters & $\begin{array}{c}\text { Correlation value } \\
\text { (Spearman's Rho } \\
\text { Test) }\end{array}$ & $\begin{array}{c}\text { Correlation with } \\
\text { nitrate } \\
\text { concentration }\end{array}$ \\
\hline 1 & $\begin{array}{l}\text { Age of } \\
\text { settlement }\end{array}$ & 0.147 & Low \\
\hline 2 & House density & 0.116 & Low \\
\hline 3 & $\begin{array}{l}\text { Sanitation } \\
\text { arrangement }\end{array}$ & 0.203 & Low \\
\hline 4 & $\begin{array}{l}\text { Sanitation } \\
\text { behavior }\end{array}$ & 0.018 & No relationship \\
\hline
\end{tabular}

\subsection{Impact of Combination Factors}

Based on the result above, each factor is low relationship with nitrate concentration. Anyway, all factors have influence with nitrate concentration not only due to one factor but all factors should be combined together and this combination may be shown better relationship with nitrate concentration than one factor. That is why it is necessary to try to combine all factors related to the contaminant loading factors. According to the result above, three factors are combined together because combination of these factors can make a good relationship with nitrate concentration. Whereas, water use patterns is not included in this combination because it has very low relationship with nitrate concentration.

\section{Score evaluation}

Specifically for contaminant loading factor parameters, scores are rule-based in which ratings are given to each class of a parameter on the basis of a certain suitable a particular location which is for contaminant load. Thus, each class of a parameter is reclassified to a score, giving higher values to each class which is more suitable for contaminant load. The following Table 2 is shown about the scores related to classes of factors.

\section{Weight evaluation}

After giving a score to each class of a parameter, higher weight values are given to this parameter which is considered more importance of parameter. Based on boxplot and column diagram above, the higher percentage influence 
Table 2: Relationship between classes of contaminant loading factors and scores.

\begin{tabular}{l|c|c}
\hline \multicolumn{1}{c|}{ Factors } & Classes & Scores \\
\hline House density & High & 3 \\
& Moderate & 2 \\
& Low & 1 \\
\hline Sanitation & $<10 \mathrm{~m}$ & 2 \\
arrangement & $>10 \mathrm{~m}$ & 1 \\
\hline Age of & $<20$ years & 1 \\
settlement & $20-60$ years & 2 \\
\hline
\end{tabular}

Table 3: Relationship between contaminant loading factors and weights.

\begin{tabular}{l|c}
\multicolumn{1}{c|}{ Factors } & Weights \\
\hline Sanitation arrangement & 0.5 \\
\hline Age of settlement & 0.3 \\
\hline House density & 0.2 \\
\hline
\end{tabular}

is weighted to the more importance of parameters. The following Table 3 is shown about the weights related to factors.

The Figure 13 shown about map of combination of three factors.

According to boxplot diagram (Figure ??), it shows a better relationship than one factor between contaminant loading class and nitrate concentration because the average value of nitrate concentration is following this order; high load $>$ moderate load $>$ low load but it has still low relationship with nitrate concentration because the variation from high to low does not show a very good relationship.

Although the diagram of combination of these factors have a good relationship with nitrate concentration (average), the variation of nitrate concentration from high to low shows a low relationship. Therefore, the importance of groundwater vulnerability cannot be overlooked in explaining the variation in contaminant concentration (Holman et al., 2005, Putra, 2007) because the most logical approach to assess the occurrence of groundwater contamination is to regard it as an interaction between the contaminant loading and the intrinsic groundwater vulnerability at the location concerned (Foster \& Hirata, 1988 and Morris et al., 2003). It means that actual contamination at a location concerned is defined not only by the contaminant loading, but also by the ease with which a contaminant can reach groundwater (a pa-

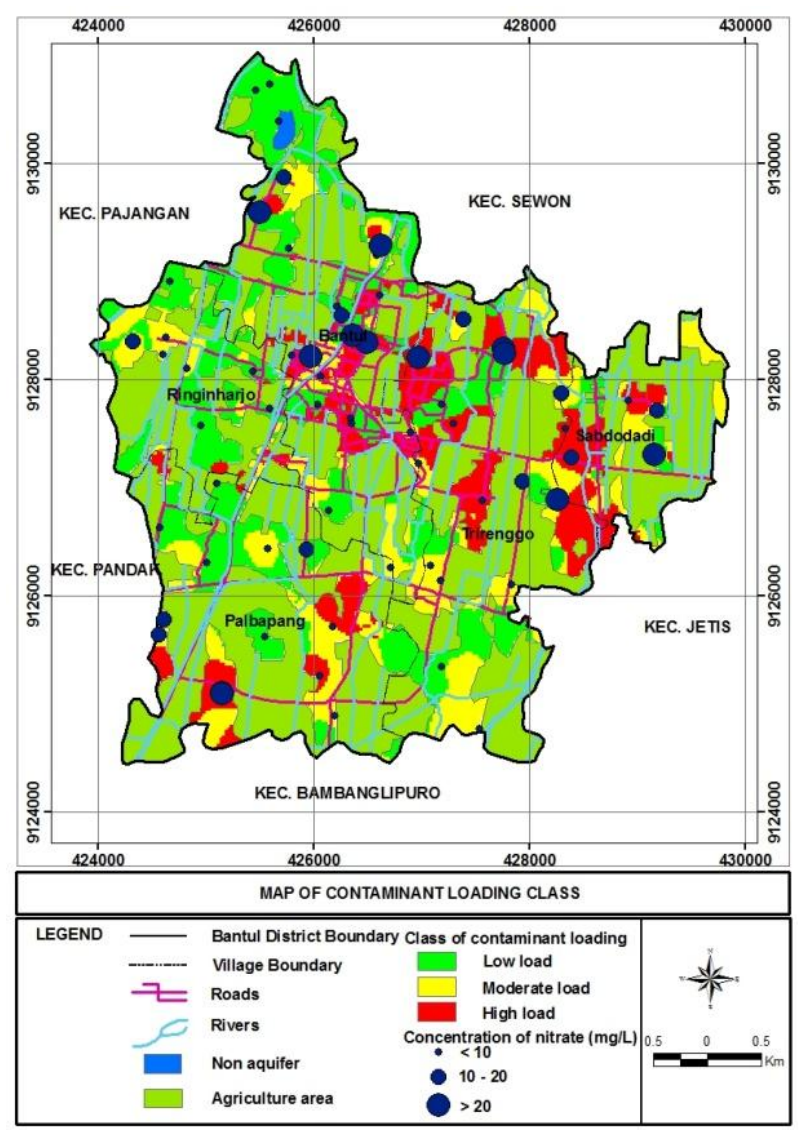

Figure 12: Map of contaminant loading class.

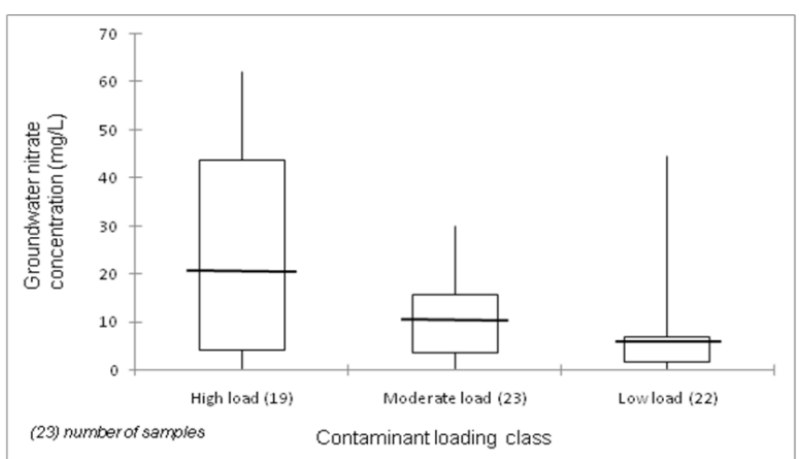

Figure 13: Boxplot diagram of nitrate concentration in shallow groundwater from contaminant loading class within the study area. 
rameter estimated by intrinsic groundwater vulnerability) that is applied to the same location (Panagoupolos et al., 2006, Putra, 2007).

\section{Conclusion}

The quality of groundwater underlying Bantul district has been deteriorated by the leakage of unsewered and residential area containing high concentration of nitrate. Without any actions, the further release of the nitrate to groundwater compounding to the current condition could result in a huge environmental and socioeconomic loss. Therefore, the research study on "The Impact of Sanitation on Groundwater Nitrate Level" at Bantul district through hydrogeological investigation and contaminant loading factors of on-site sanitation are undertaken in order to understand the groundwater flow patterns as well as the effect of contaminant loading factors on the nitrate concentration in groundwater. Based on data analysis and research findings, the conclusion can be drawn as the followings:

- Although the older house of settlement has the possibility of high nitrate loading to the groundwater, the result has shown a low relationship with nitrate concentration since the age of settlement is less than 60 years old in Bantul district.

- The closeness of the septic tank to well has the possibility of high nitrate loading to the groundwater because the result has shown a relationship with nitrate concentration.

- Both the high house density and moderate house density has resulted in the possibility of high nitrate loading to the groundwater based on their type of settlement.

- The higher water use in the house is not shown the possibility of high amount of nitrates loading to the groundwater because it has no relationship with nitrate concentration.

\section{Acknowledgment}

As a requirement for master's degree study, this research is compulsory to be established.
It is a kind of collaborative research under ASEAN University Network/Southeast Asia Engineering Education Development Network (AUN/SEED-Net) project. I would like to thank to Japanese International Cooperation Agency (JICA) and Indonesian Government who support all the expense for this research. Finally, I would like to thank also to my partner Mr. Kukuh Jalu Waskita who help me to conduct field work.

\section{References}

ARGOSS (2001), Guidelines for Assessing the Risk to Groundwater from On-site sanitation, British Geological Survey Commissioned Report, CR/01/142, 97 p.

Foster, S., and Hirata, R. (1988), Groundwater Pollution Risk Assessment; A methodology Using Available Data, PAN American Center for Sanitary Engineering and Environmental Sciences (CEPIS), Lima, Peru.

Holman, I.P., Palmer, R.C., Bellamy, P.H., and Hollis, J.M. (2005), Validation of an intrinsic groundwater pollution vulnerability: methodology using a national nitrate database, Hydrogeology Journal, Vol. 13, p. 665 - 674, Springer-Verlag

IRC International Water and Sanitation Centre (2007), Enhancing Livelihoods Through Sanitation, The Netherlands.

Morris, B.L., Lawrence, A.R., Chilton, P.J.C., Adams, B., Calow, R.C., and Klinck, B.A. (2003), Groundwater and its susceptibility to degradation: A global assessment of the problem and options for management. Early Warning and Assessment Report Series, RS.03-3. United Nations Environment Program, Nairobi, Kenya.

Panagopoulos, G.P., Antonakos, A.K., and Lambrakis, N.J. (2006), Optimization of the DRASTIC method for groundwater vunerability assessment via the use of simple statistical methods and GIS, Hydrogeology Journal, Vol. 14, No.6, P. 894 - 911, Springer-Verlag.

Prastoro, R.A. (2009), Groundwater Pollution Risk of Unconfined Aquifer by Nitrate in Bantul and Bambanglipuro district, Bantul Regency, Yogyakarta, Indonesia.

Putra, D.P.E. (2003), Integrated Water Resources Management in Merapi - Yogyakarta Basin, ASEAN University Network/South East Asia Engineering Education Development Network (AUN/SEED-Net), Yogyakarta (Unpublished Report). 
Putra, D.P.E. (2007), The Impact of urbanization on Groundwater Quality: A case study in Yogyakarta city - Indonesia. Mitteilungen zur Ingenieurgeologie und Hydrogeologie, Heft 96, 148 S,
Okt 2007, Herausegeben vom Lehrstuhl fuer Ingenieurgeologie und Hydrogeologie, Univ.-Prof. Dr. R. Azzam, RWTH Aachen, Germany. No. ISBN: 3-86130-281-0 